\title{
EFFECTS OF WATER STRESS ON THE GROWTH AND REPRODUCTION OF BLACK GRAM (VIGNA MUNGO L.)
}

Dahanayake Nilanthi*, AL Ranawake and DD Senadhipathy

Department of Agricultural Biology, Faculty of Agriculture, University of Ruhuna, Mapalana, Kamburupitiya, Sri Lanka

Accepted: $24^{\text {th }}$ September 2014

\begin{abstract}
Black gram (Vigna mungo L.; Fabaceae) is one of the most highly prized pulses in tropical countries especially in India. The green pods are eaten as vegetable and they are highly nutritious. Grain legumes play a vital role in improving soil health through biological $\mathrm{N}$ fixation and are the cheapest source of dietary protein for human and livestock. Their yield is low and unstable due to water stress during growth stages. Low rain fall with concomitant high temperature along with the increased solar radiation due to reduced cloud cover is responsible for limited water supply to crops in many tropical regions which results in shortages of black gram around the world. Water is a primary input not only in enhancing the crop production but also involved directly or indirectly in all the physiological processes in plants which directly changes morphological characters of plants. In the present study changes in morphological characters due to the ten-day water stress were observed at vegeta-tive and reproductivestages (flowering stage and fruiting stage). All characters observed viz. plant height, wet and dry weight of shoots and roots, root length, number of pods, wet and d ry weight of pods, wet and dry weight of seeds were significantly affected by the water stress condition. Water stress at vegetative stage seriously limited the plant height, wet and dry weight of shoots and roots and root length, whereas water stress at reproductive stage showed clear impact on the number of pods, wet and dry weight of pods, wet and dry weight of seeds. The least plant height $(46.76 \mathrm{~cm})$ and root length $(15.98 \mathrm{~cm})$ were observed at vegetatives tage under water stress while control plants showed $88.89 \mathrm{~cm}$ plant height and $21.85 \mathrm{~cm}$ root length. The reduction of the number of pods per plant was more pronounced under soil moisture stress at the flowering stage compared to that under fruiting stage. Therefore, the least number of pods per plant, 2.04, and wet weight of seeds per pod, $\mathbf{0 . 0 0 3 1} \mathrm{g}$, were ob-served in plants stressed at flowering stage while plants under controlled conditions showed 14.9 pods per plant and $0.0907 \mathrm{~g}$ of seed wet weight per pod . Water stress at fruiting stage resulted in a wrinkling appearance of seeds with unfilled grains. Number of root nodules was reduced significantly due to drought condition at vegeta-tive stage compared to that under reproductive stages.
\end{abstract}

Key words: Black gram, Water stress, Vegetative stage, Reproductive stage

\section{INTRODUCTION}

Black gram (Vigna mungo L.) being a legume, it enriches soil $\mathrm{N}$ content and has relatively a short (90-120 days) life span(http:// www.commoditiescontrol.com/eagritrader/ commodityknow ledge/blackgra m/ blackgram 1.htm). It is originated in India where it has been cultivated from ancient times and is one of the most highly prized pulses in India. Although it has been introduced to other tropical areas mainly by Indian immigrants about $70 \%$ of the world's Black gram still comes from India.

Black Gram is a perfect combination of all nutrients which include 20 to $25 \%$ of proteins, 40 to $47 \%$ of starch along with ash, fats, carbohydrates and essential vitamins. It is boiled and eaten directly or used after splitting into dhal. It is extensively used in various culinary preparations and recommended for diabetes. Available from: (http://en.wikipedia.org/wiki/ Vigna_mungo). The green pods are eaten as a

*Corresponding author: nilanthi@agbio.ruh.ac.lk 
vegetable which is highly nutritious. The hulls or the outer covering of gram and straw are used as a cattle feed.

Plant growth and development of black gram are greatly influenced by various environmental factors such as temperature, light, water and nutrient availability (Rajam, 1997).Under abiotic stress conditions, where variations of above factors affect plant growth and development adversely resulting in a dramatic reduction of the crop yield.

The main objective of the study was to estimate the impact of water stress at vegetative and reproductive stages on plant growth and development.

\section{MATERIALS AND METHOD}

\section{Plant material}

Black gram (variety MI 1) was used for the study and seeds were bought from Research Center, Department of Agriculture. Forty pots of Black gram were arranged in the research field at the Faculty of Agriculture, University of Ruhuna, Sri Lanka.

\section{Nursery preparation}

Nursery medium was prepared using top soil: cow dung: compost at the rate of $1: 1: 1$. Nursery medium was sterilized using the fungicide, Bathione, to prevent soil born pests and diseases. Seeds were first germinated under water soaked conditions in nursery beds for three weeks.

\section{Transferring seedlings to pots}

After germination, morphologically uniform seedlings having well developed roots were selected and transferred in to pots which were filled with sterilized potting mixture and applied the basal dressing (Urea 35, Triple super phosphate 100, Murate of potash $75 \mathrm{Kg} / \mathrm{ha}$ ) and top dressing was applied about 30 days after sowing (Urea $30 \mathrm{~kg} / \mathrm{ha}$ ). Seedlings were planted with three seedlings per pot thinned out weaker plants after 10-12 days leaving only two plants per each pot.

\section{Imposing water stress}

Plants were subjected to the water stress by withholding the water supply for 10 days at different growth stages viz,. vegetative (T1), flowering (T2) and fruiting (T3)(pod filling) stages. Control (T4) pots were watered daily to maintain the soil moisture. Rest of the management practices were maintained uniformly according to the recommendations of the Department of Agriculture, Sri Lanka from seed germination to harvesting.

\section{Data collection}

Plant height, wet and dry weight of shoots and roots, root length, number of pods, wet and dry weight of pods, wet and dry weight of seeds were taken in three different stages i.e. vegetative, flowering and fruiting.

\section{Data analysis}

Randomized Complete Block Design (RCBD) with ten replicates was used. Treatments were randomized using a random table. Forty pots were used for experiment with two plants per one pot. Complete Statistical analysis was carried out using the Student Newman-Kuells Means Separation Test of SAS program (9.1.3).

\section{RESULTS AND DISCUSSION}

Results revealed that all the growth and yield parameters considered in the experiment were significantly affected by the water stress condition (Table 1). Water stress at vegetative stage showed significant impact $(\mathrm{P}<0.05)$ on all vegetative growth aspects of above and below ground components i.e. plant height, wet and dry weight of shoots and roots and root length. For example, the least plant height $(46.76 \mathrm{~cm})$ and root length $(15.98 \mathrm{~cm})$ were observed when water stress was applied during vegetative stage while control plants showing plant height of $88.89 \mathrm{~cm}$ and root length of 
$21.85 \mathrm{~cm}$. This retarded growth at the vegetative stage would have imminent dragging effects on subsequent flowering and fruiting stages. Chaves (1991) and Yordanov et al. (2000) observed soil water deficit lead to a progressive suppression of photosynthetic carbon assimilation which was clearly shown in plant morphological characters. Moreover, Yordanov et al. (2003) also reported that the decreasing photosynthetic rate was a result from stomatal and non-stomatal (biochemical) limitations. Therefore, the restricted photosynthetic assimilation due to water stress would have been the cause for the retarded vegetative growth of black gram plants. pod (Table 1). Hence, the exposure to dry spells during flowering stage appears more critical on the yield aspects of black gram. Similar effects have been observed by Wang et al. (2003). Drought stress has been identified as one of the major causes for crop losses world wide which reduces average yields more than $50 \%$.

Not only the number but also the quality of seeds was affected by the exposure to the drought especially at fruiting stage. Thus it resulted the seed appearance of wrinkled nature with unfilled grains because of the water stress at fruiting stage (Fig 2). Some observa-

Table 1. Effect of water stress on the growth and development of Black gram plant at vegetative, flowering and fruiting stages

\begin{tabular}{|c|c|c|c|c|c|c|c|c|c|c|c|}
\hline Treatment & $\begin{array}{l}\text { Plant } \\
\text { Height } \\
(\mathrm{cm})\end{array}$ & $\begin{array}{l}\text { Shoot } \\
\text { Wet } \\
\text { Weight } \\
\text { (g) }\end{array}$ & $\begin{array}{l}\text { Shoot } \\
\text { Dry } \\
\text { Weight } \\
\text { (g) }\end{array}$ & $\begin{array}{l}\text { Root } \\
\text { Length } \\
(\mathrm{cm})\end{array}$ & $\begin{array}{l}\text { Root } \\
\text { Wet } \\
\text { Weight } \\
\text { (g) }\end{array}$ & $\begin{array}{l}\text { Root } \\
\text { Dry } \\
\text { Weigh } \\
\mathrm{t} \\
(\mathrm{g}) \\
\end{array}$ & $\begin{array}{l}\text { Number } \\
\text { of } \\
\text { Pods }\end{array}$ & $\begin{array}{l}\text { Wet } \\
\text { Weight } \\
\text { of pods } \\
\text { (g) }\end{array}$ & $\begin{array}{l}\text { Dry } \\
\text { Weight } \\
\text { of pods } \\
\text { (g) }\end{array}$ & $\begin{array}{l}\text { Wet } \\
\text { Weight } \\
\text { of seeds } \\
(\mathrm{g})\end{array}$ & $\begin{array}{l}\text { Dry } \\
\text { Weight } \\
\text { of seeds } \\
\text { (g) }\end{array}$ \\
\hline $\begin{array}{l}\text { Withholding water } \\
\text { at vegetative } \\
\text { stage (T1) }\end{array}$ & $46.76^{d}$ & $13.51^{\mathrm{d}}$ & $3.50^{\mathrm{c}}$ & $15.98^{\mathrm{d}}$ & $1.29^{\mathrm{c}}$ & $1.14^{\mathrm{c}}$ & $8.17^{\mathrm{b}}$ & $0.17^{\mathrm{b}}$ & $0.15^{\mathrm{b}}$ & $0.0474^{\mathrm{b}}$ & $0.0451^{\mathrm{b}}$ \\
\hline $\begin{array}{l}\text { Withholding water } \\
\text { at flowering } \\
\text { stage (T2) }\end{array}$ & $65.04^{\mathrm{c}}$ & $11.89^{c}$ & $6.10^{b}$ & $20.32^{\mathrm{c}}$ & $2.22^{b}$ & $2.17^{\mathrm{b}}$ & $2.04^{\mathrm{d}}$ & $0.06^{\mathrm{c}}$ & $0.05^{\mathrm{c}}$ & $0.0031^{\mathrm{d}}$ & $0.0024^{\mathrm{d}}$ \\
\hline $\begin{array}{l}\text { Withholdingwaterat } \\
\text { fruiting } \\
\text { stage (T3) }\end{array}$ & $70.61^{b}$ & $13.51^{\mathrm{b}}$ & $6.67^{b}$ & $21.85^{\mathrm{b}}$ & $2.52^{b}$ & $2.38^{\mathrm{b}}$ & $4.33^{\mathrm{c}}$ & $0.09^{c}$ & $0.08^{\mathrm{c}}$ & $0.0084^{\mathrm{c}}$ & $0.0059^{c}$ \\
\hline Control(T4) & $88.89^{a}$ & $17.61^{\mathrm{a}}$ & $10.29^{\mathrm{a}}$ & $37.72^{\mathrm{a}}$ & $4.03^{\mathrm{a}}$ & $3.90^{\mathrm{a}}$ & $14.90^{\mathrm{a}}$ & $0.47^{\mathrm{a}}$ & $0.45^{\mathrm{a}}$ & $0.0907^{\mathrm{a}}$ & $0.0868^{\mathrm{a}}$ \\
\hline C.V. $(\%)$ & 3.09 & 8.47 & 12.84 & 5.11 & 17.87 & 18.24 & 16.95 & 18.14 & 18.70 & 9.70 & 10.1748 \\
\hline
\end{tabular}

Means fallowed by the same lower case letters within each column indicate no significant difference at $\mathrm{P}<0.05$

Water stress at reproductive stages had significant effects $(\mathrm{P}<0.05)$ on all yield related parameters such as number of pods, wet and dry weight of pods, wet and dry weight of seeds (Table 1). However, it is noteworthy that, water stress during the flowering stage has shown more pronounced effects on -yield parameters than that of the fruiting stage. Thus, the least pod number per plant 2.04 and wet weight of seeds per pod $0.0031 \mathrm{~g}$ were observed in plants stressed at flowering stage while control plants showing 14.9 pods per plant and $0.0907 \mathrm{~g}$ of seed wet weight of a tions have been reported showing the effects of drought stress on nitrogen fixation of the legume-rhizobium symbiosis (Serraj, 2003). Similar results were observed in the present study also where the number of root nodules was significantly reduced due to drought condition specially at vegetative stage compared to that in reproductive stages. Usually formation of root nodules and biological $\mathrm{N}$ fixation start at the beginning of plant growth and hence soil moisture stress at the vegetative stage severely restricts the formation of root nodules. 


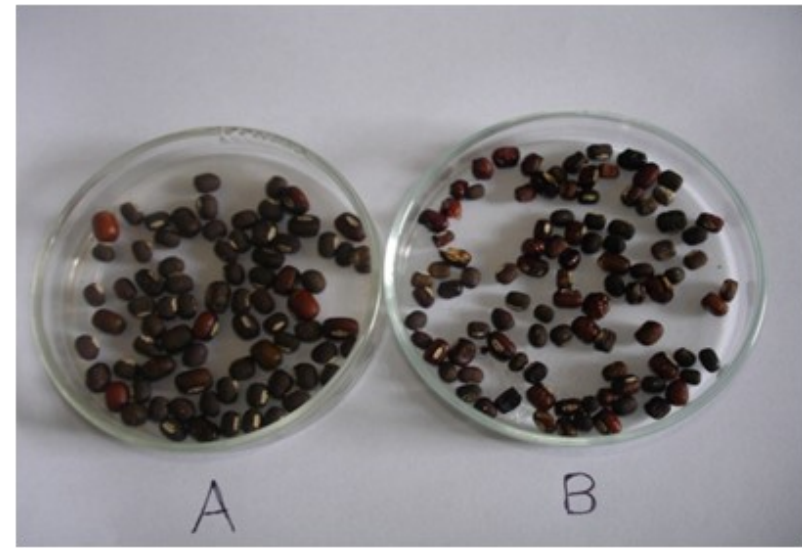

Fig. 2. Effects of water stress on the appearance of seeds A. Control (with larger, unwrinkled seeds) and $B$. Water stressed (smaller, wrinkled seeds) at reproductive stage

\section{CONCLUSION}

Water stress on Vigna mungo L. plants at vegetative stage significantly restricted the vegetative growth of the plants while the application of water stress at reproductive stages directly affected on yield. It not only reduced the number of seeds but also resulted in the change of the appearance of seeds with pronounced wrinkling of the outer skin with unfilled grains.

\section{REFERENCES}

Chaves MM 1991 Effects of water deficits on carbon assimilation. Journal of Experimental Botany. 42:1-16.

Serraj R 2003 Effects of drought stress on legume symbiotic nitrogen fixation: physiological mechanisms. Indian $\mathrm{J}$ Exp Biol. 41(10):1136-1141.

Wang WB, Vinocur A, Altman 2003 Plant responses to drought, salinity and extreme temperatures: towards genetic engineering for stress tolerance. Planta, 218: 1-14.

Yordanov IV, Velikova T, Tsonev 2003 Plant responses to drought and stress tolerance. Bulg. J. Plant Physiol, Speacial issue. $187-206$.

Yordanov IV, Velikova T, Tsonev 2000 Plant responses to drought acclimation and stress tolerance. Photosynthetica, 38: $171-186$.

Commodity info services LLP, 333-34, Laxmi Plaza, Laxmi Industrial Estate, New Link Road, Andheri (west), Mumbai$\begin{array}{lllllll}4 & 0 & 0 & 0 & 5\end{array}, \quad \mathrm{~h} \mathrm{t} \mathrm{p}: / /$ www.commoditiescontrol.com/ eagritrader/commodityknowledge/ blackgram/blackgram1.htm, Retrieved on 12.05.2014. 